\title{
The Origins and Significance of Gerald S. Graham's “Convoy Diary,” 1942
}

\section{Samuel McLean and Roger Sarty}

L'article suivant compare le récit "Convoy Diary », publié en temps de guerre par l'historien canadien Gerald Graham, à la version originale du 'appuie. À l'aide d'autres sources traitant du convoi et de la carrière de Graham, l'analyse conclut que les deux récits sont des comptes rendus fidèles des opérations navales, qui révèlent les réactions émotionnelles et intellectuelles de l'historien à la traversée difficile de l'Atlantique Nord. Parallèlement, la censure des informations militaires et la révision approfondie que Graham a lui-même apportée à son texte ont extrait de la version publiée certains des renseignements les plus intéressants sur les opérations de convoi, l'intensité de l'expérience et le rôle important qu'elle a joué dans sa vie.

"Convoy Diary," first published in October 1943, is the intensely personal account by Canadian historian and wartime naval officer Gerald S. Graham (19031988) of his North Atlantic passage home from duty in Britain. ${ }^{1}$ Graham had sailed as a guest aboard the Royal Navy destroyer HMS Harvester, the senior escort for convoy ON 126 from Liverpool, England to North America. It was a slow convoy and stormy conditions almost brought the struggling ships to a standstill, prolonging the voyage to nearly three weeks, from late August to mid September 1942. The convoy departed at the beginning of what in fact proved to be the most intense part of the struggle against the German submarine fleet, and encountered one of the fierce gales that made the lives of Allied seamen still more miserable during months of weather that was harsh even by North Atlantic standards. The article is a vivid and precise record of a difficult - if fortunately bloodless - crossing that captured telling detail of life in a small warship seldom if ever related in official reports. No

\footnotetext{
1 “Convoy Diary," University of Toronto Quarterly, 13 (October 1943), 102-116. The authors gratefully acknowledge the support of the Social Sciences and Humanities Research Council of Canada, which funded research for this study.
}

The Northern Mariner/Le marin du nord, XXVI, No. 2 (April 2016), 165-196. 


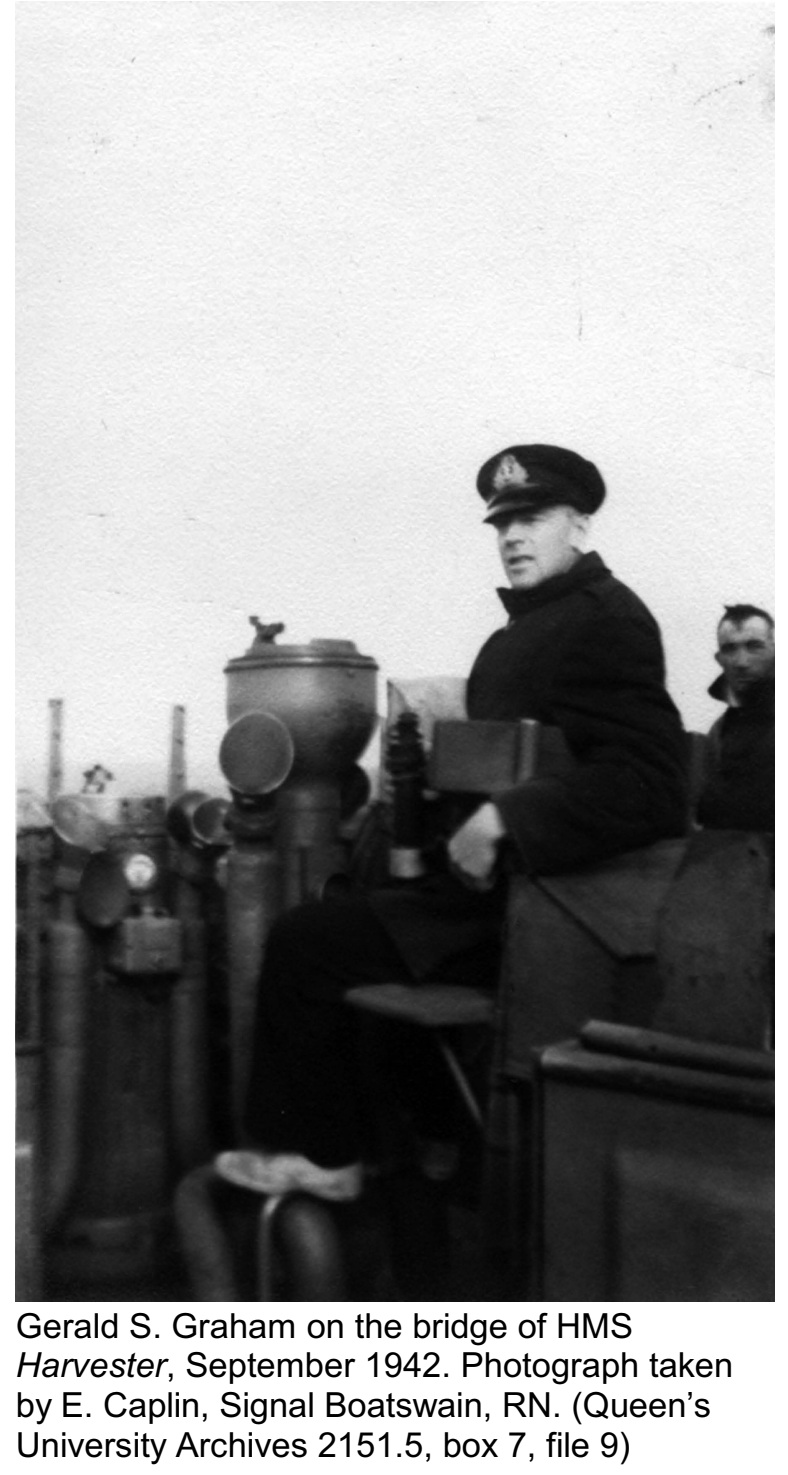

doubt that is why The Naval Review, the professional journal of the Royal Navy, reprinted the piece in May $1946 .^{2}$ It was a shortened version, the editor dropping some of the paragraphs about shipboard routine that would presumably not have interested the readership of serving and retired Royal Navy officers. Like the 
original publication, the abridged version in the Naval Review does not include technical and tactical information that had been removed under wartime censorship. ${ }^{3}$

Graham, it turned out, kept the black, hard cover notebook in which he wrote the original diary. ${ }^{4}$ In March 2008 his eldest daughter, art historian Laura Brandon, lent it to Roger Sarty. ${ }^{5}$ Although the challenges of the handwriting made detailed comparison with the published versions difficult, it was clear that the original contained significant additional material, beyond the passages that had been cut for military censorship. Samuel McLean decoded the handwriting, made a transcription and began research on obscure references. The clean text showed that Graham considerably reworked it for the University of Toronto Quarterly, polishing the prose and cutting about a third of the original diary. ${ }^{6}$ Missing are some of the personal opinions, particularly Graham's disdain for Canada's "narrow nationalism," which he believed had made the Canadian war effort less effective than it might have been with closer collaboration with Britain. Although many of the original passages about the discomfort and fear he experienced remain in the published version, the compressed and more literary final product are not as evocative as the raw account. Material that had been cut by the censors, moreover, showed that Harvester's commanding officer and the senior officer of escort group B3, Commander Arthur André Tait, RN, an experienced and decorated escort commander, kept Graham closely apprised about possible U-boats in the vicinity of the convoy. Graham's original account painted a good picture of the information available to an escort commander, its sources, and how he used it.

Other commitments interrupted the work on the diary until recently. In picking up the threads we benefited greatly from the help of Robert Fisher, now a senior archivist at Library and Archives Canada, who did an analysis of ON 126's passage from the full German as well as Allied records when he was a member of naval

\footnotetext{
3 "Convoy Diary" (1943), 102, n1.The version in the University of Toronto Quarterly was approximately 6,000 words in length; that in the Naval Review about 4,500 words.

${ }^{4}$ Hereafter, cited as "UK diary notebook." On the first page is the handwritten notation "SECRET. This book is to be kept in the custody of an officer," signed by Captain R.I. Agnew, captain commanding Canadian ships, at the RCN's offices in London. Agnew was the senior Canadian authority through whom Graham made his arrangements (see entries for 23 and 30 June 1942). The notation indicates that Graham discussed his intention to keep a diary with Captain Agnew, and explains the note in the University of Toronto Quarterly publication that "The author was permitted to keep this diary" $(102, \mathrm{n} 1)$.

5 This was part of Dr. Brandon's exceptional assistance in locating and providing access to the large body of Graham's papers then held by the family. Dr. Brandon subsequently deposited these papers, including the notebook that contains the hand-written diary, at the Queen's University Archives, where we have had excellent help from archivist Heather Home. We are grateful to Dr. Brandon and her siblings for supporting publication of the present transcript; John Graham, Gerald Graham's eldest son, kindly responded to inquiries about obscure references.

${ }^{6}$ A twenty-three page typescript with minor pencilled amendments in Graham's hand that is very close to the version published in University of Toronto Quarterly is in a file entitled "Correspondence Personal Very Miscellaneous" in the papers from the family. The typescript is missing p. 1, but otherwise complete.
} 
official history team at the Directorate of History, National Defence Headquarters. His research included high level British and American intelligence files that were opened only in the 1980 s. $^{7}$

Graham, one of the prolific and prominent Canadian historians who embarked upon their careers in the 1930s, was a professor at Queen's University in Kingston. He trained with the university's Canadian Officer Training Corps hoping to enter the army as a historical officer. The top generals knew him, thought highly of his work and personal qualities, and (unknown to Graham) were on the verge of creating a position for him when, in the spring of 1942, he suddenly joined the navy. One of his friends persuaded him to accept an appointment in the rank of instructor lieutenant commander to teach history to officer cadets at the new naval college, HMCS Royal Roads at Esquimalt, near the RCN's Pacific base just south of Victoria, BC. ${ }^{8}$

An attractive benefit of this position was that he could go to the United Kingdom to investigate how the Royal Navy taught history in its training establishments. Graham, the son of British emigrants with close ties to family in the old country, had done his PhD at Cambridge University in 1927-29, loved England and was a passionate exponent of the British Empire; he saw Canada's war effort as an integral part of a British-led struggle for civilization. He was also well connected in Royal Navy circles, having closely consulted two leading sailors-turnedhistorians, Admirals Herbert W. Richmond and Henry G. Thursfield, for his own work on naval aspects of Canada's economic development in the late eighteenth and early nineteenth centuries.

Graham arrived in England in June 1942 via a trans-Atlantic flight in a bomber aircraft, and for the next ten weeks enjoyed extraordinary access to senior officers and civilian officials, and to British high society. He was all the while profoundly moved by the suffering, stoicism and determination of the British population in the war effort. ${ }^{9}$ Eager to get closer to combat, and for the opportunity to write about operations, he asked to return to Canada in a convoy escort. Graham made the request through Admiral Thursfield, and Admiral Sir Percy Noble, who as commander in chief Western Approaches was the senior British commander in the Battle of the Atlantic, personally made the arrangements: "Your Professor Graham shall have the best ship I can find and very glad to do anything I can for him."

\footnotetext{
${ }^{7}$ Robert C. Fisher, "Little to Fear? The Battle of the Atlantic, August-September 1942," (Version 4.0, unpublished narrative, Directorate of History, 1994), 41-44.

8 Roger Sarty, "The Origins of Academic Military History in Canada, 1940-1967," Canadian Military History 23 (Spring 2014), 89-91, 99.

${ }^{9}$ Samuel McLean, “'Blood and Thunder': An Assessment of Admiral Sir Herbert Richmond's Critique of Naval Education, 1939-1943," (MA major research paper, Wilfrid Laurier University, 2010) discusses Graham's consultations with Richmond and others during his 1942 mission.

${ }^{10}$ Noble to Thursfield, "Tuesday," between entries for 16 and 17 August 1942 in UK diary notebook.
} 
Commander Tait's announcement to the crew as Harvester set sail on 30 August that the "N. Atlantic was lousy with submarines which had come up from the Caribbean" accurately summarized the general situation. In January 1942 the Uboats, always in search of easy targets, had taken advantage of the United States' entry into the war to swarm into ill-protected American waters. As the Americans, with large help from the British and Canadian navies, improved their arrangements, the U-boats moved to the Caribbean and the coast of Brazil, and as defences there improved in the summer shifted back to the central part of the North Atlantic routes to attack the large convoys that sustained Britain. While the U-boat fleet was at this time gaining greatly in strength with new construction, the escort protection for the North Atlantic had been weakened to provide forces in North American waters and the Caribbean. The expanding U-boat force was able to continue to exert pressure in the western Atlantic even while concentrating more heavily in the central ocean, making it difficult to move escorts away from North American waters. The Allies, moreover, had to begin to redeploy escorts to the route from Britain to the Mediterranean to prepare for the Anglo-American offensive planned for North Africa (Operation Torch, which began on 8 November 1942). ${ }^{11}$

One result of the escort shortage was that the Allies could not divert convoys on evasive routes, clear of the expanding U-boat patrol groups in the North Atlantic. Convoys had to keep close to the most direct great circle route, and predictably Uboat headquarters quickly learned that hunting was good. The situation was still more difficult because the Allies were still unable to break into the U-boat control radio signals as a result of the Germans' introduction of four-rotor enigma encryption machines early in 1942. Meanwhile, as the Allies did not discover until later in the war, German radio intelligence was able to make timely breaks into Allied convoy control radio signals. ${ }^{12}$

The Admiralty U-boat Tracking Room did excellent work estimating enemy positions on the basis of direction finding bearings on U-boat radio transmissions, analysis of the patterns of enemy radio traffic, and information from enemy signals in low grade cyphers. Thus, as Tait's statements showed, the Admiralty tracked the build up of U-boats in the central ocean on the northern route during August. ${ }^{13}$ What the Admiralty did not and could not know until it was too late to divert the convoy was that U-boat headquarters was expecting ON 126 and had deployed twelve submarines in group Vorwärts to the south west of Iceland, across the convoy's track. The group began to close to attack as the convoy approached on 6 September.

\footnotetext{
${ }^{11}$ W.A.B. Douglas, Roger Sarty, and Michael Whitby with Robert H. Caldwell, William Johnston, and William G.P. Rawling, No Higher Purpose: The Official Operational History of the Royal Canadian Navy in the Second World War, 1939-1943, vol. 1, pt. 1, (St Catharines, ON, 2002), $477-$ 479.

${ }^{12}$ Ibid., 394-395.

${ }^{13}$ David Syrett, ed., The Battle of the Atlantic and Signals Intelligence: U-Boat Situations and Trends, 1941-1945, (Aldershot, UK, 1998), 65-79.
} 
Graham's account shows how Tait used his escorts' radar and direction finding equipment to build up a picture of the developing threat. German records reveal that the lead submarines actually sighted the escorts, which Tait did not believe they had, but he was correct in his conclusion that they could not maintain contact because of the appalling weather conditions. Those records also confirm Graham's account that the U-boats regrouped and were then able to attack ON 127, a fast convoy which had sailed five days after ON 126 but was able to close to within 300 miles or less because of its higher speed. The radio reports of the heavy losses to ON127, including the destruction of the Canadian destroyer HMCS Ottawa, were all the more chilling because, as Graham's account rightly suggests, the slow ON 126 would have been much more vulnerable to sustained attack.

The original diary, more than the published version, shows in intimate detail how the cool professionalism and warm humanity of the officers with whom Graham lived in such close quarters enabled him to endure the terror of the enemy's close pursuit and the harrowing Atlantic weather. News of Harvester's sinking by a U-boat's torpedoes on 11 March 1943 during the intense battle for HX 228 was a hard blow. There was heavy loss of life, including Commander Tait and five other officers with whom Graham had sailed. He sent a tribute to the lost officers, with fond recollections of the nearly three weeks he had been in their company, to the The Times of London. "I learned much from H.M.S. Harvester," the tribute concluded, "that I will never forget."

Graham appended a moving account of Harvester's loss and the fate of the officers to the manuscript of "Convoy Diary" 15 he submitted to the University of Toronto Quarterly. Graham was already in contact with the families of the officers, who were extremely touched by the tribute in The Times, and he sent them copies of the University of Toronto Quarterly publication. "I am more grateful than I can say," wrote Canon Arthur Tait, Commander Tait's father, "for your kindness in sending me a copy of your booklet on convoy work in my dear Andre's ship. I have read it with a thrilling interest; \& it has helped me, more than anything that he allowed me to know, to realize something of the life on Board..." ${ }^{16}$ Graham got in touch with several of the families when he next returned to the UK in the summer of 1944.

\footnotetext{
14 “Personal Tributes: H.M.S. Harvester," The Times (London), 10 June 1943, 7

15 The account of Harvester's loss does not appear in the typescript draft cited in note 6 above.

16 Arthur Tait to Graham, 18 January 1944, UK diary notebook. Arthur James Tait, DD (18721944) was canon of Peterborough Cathedral from 1924 until his death. He passed away on 3 April 1944. "Canon A.J. Tait," The Times (London), 5 April 1944, 7
} 


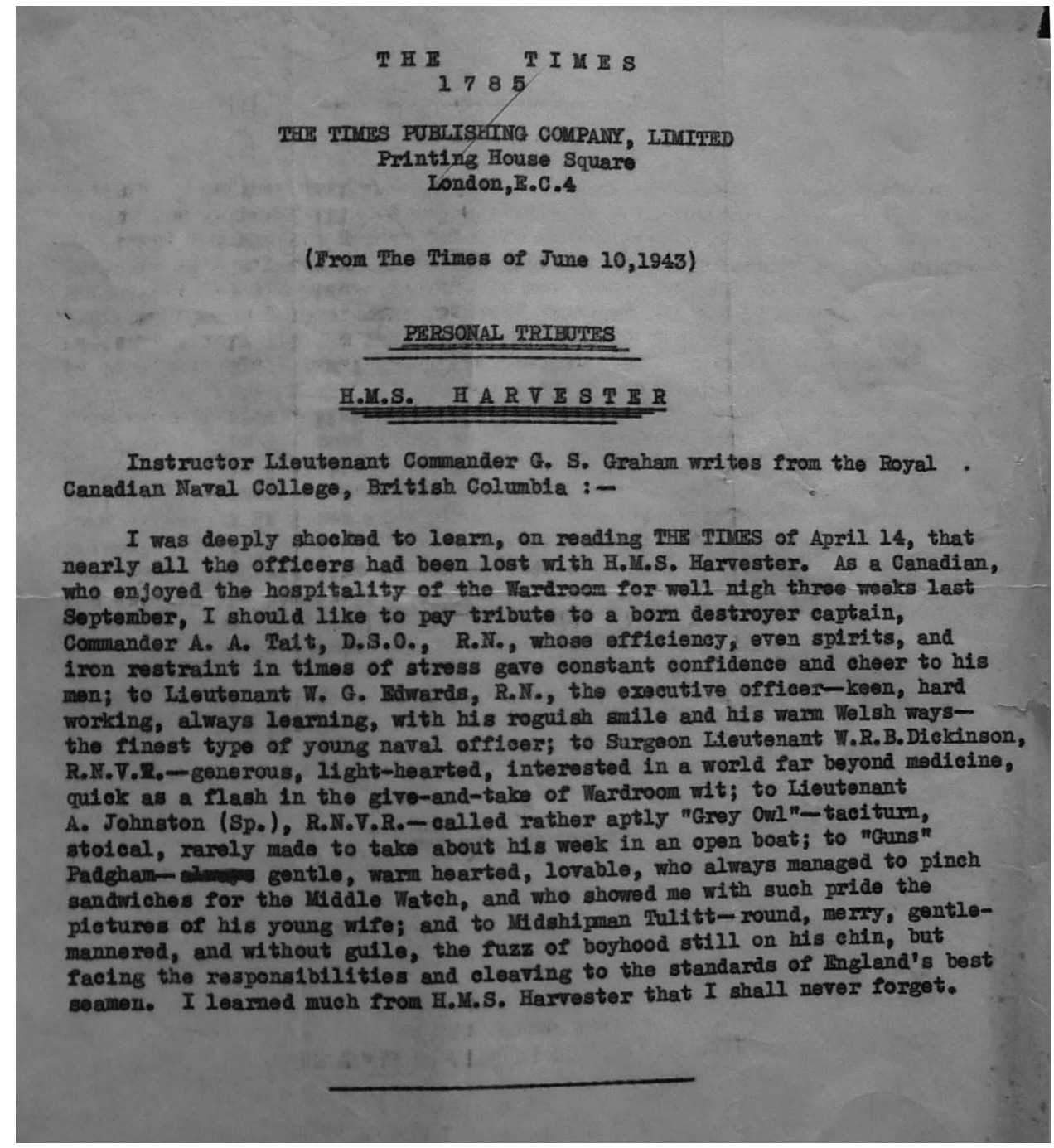

Graham's tribute to the six officers lost in the sinking of HMS Harvester on 11 March 1943, published in The Times of London. (Queen's University Archives 2151.5, box 7 , file 9)

It was the powerful experiences of Graham's trip in 1942, and particularly his time in Harvester, that brought him to lobby hard to go back to the British Isles in 1944. His earlier efforts to persuade the navy to allow him to go overseas every summer to help record the war effort had come to nought, and as an instructor in British Columbia he felt entirely isolated from the events (and people) that mattered. Once back in England in1944, Graham drew on his army contacts to leave the navy, 
take an army commission, and join the historical section at Canadian Military Headquarters in London as a senior historical officer.

At the end of Graham's army service in London in 1946, he decided not to return to Canada. He resigned his position as a full professor at Queen's and accepted a junior position as a lecturer at the University of London. It was during this time that he revived a project for a short book on the influence of the Royal Navy on Canadian history that he had set aside when he joined the navy. He greatly expanded the scope into a study of the rise of Britain's sea power in conflicts with European rivals and then the United States from the $17^{\text {th }}$ to the $19^{\text {th }}$ centuries. In fact the project marked a fundamental transition in Graham's work from Canadian history to the naval history of the British Empire, which he pursued on a global scale for the rest of his life. Empire of the North Atlantic: The Maritime Struggle for North America, a book of some 350 pages, appeared in 1950. The dedication was

To the Officers and Ship's Company

of

H. M. S. Harvester

lost in the North Atlantic by enemy

action, March 11, 1943, while on

convoy escort duty 


\title{
Gerald S. Graham's Manuscript Diary of His Voyage in HMS Harvester, 1942
}

\author{
Transcribed and annotated \\ by Samuel McLean and Roger Sarty
}

\section{Editorial note}

We have endeavoured to reproduce the handwritten text, with one exception. Graham often inserted dashes after commas and periods, and we have left these out except in the cases where they signal a significant break in the prose. He used square brackets for some parenthetical statements, and so we have used double curve brackets -\{\} - for our insertions.

Greenock - Gourock

Aug. 29. Saturday 1942

I was a little concerned about getting on the Harvester ${ }^{1}$ on time, so hastened in the van to Gourock pier to be told she was gone, this was a blow, but enquiry disclosed she was riding at Greenock so away we tore to Captain D., ${ }^{2}$ where I learned she was oiling, but missed the barge. Thence to the ferry which I caught kit and baggage at $10 ; \&$ after visiting half the fleet finally found Harvester and clambered on board. My baggage was taken to Cmdr. Tait's cabin, - a luxurious suite and I was told I could stay there as soon as we put to sea. (Meanwhile I had a sleeping bunk with the Middy.). Met my ship-mates, $1^{\text {st }}$ Lt. Edwards, Lt. Briggs, Lt. Green, Sub. Lt. Kendall, Eng. Lt. Dickinson. Guns, Radio. Lt. , \& the Engineer,

\footnotetext{
${ }^{1}$ HMS Harvester - Havant class destroyer built for Brazil but requisitioned by the Royal on the outbreak of war, and completed in February 1940. She was senior ship of Escort Group B3 in Western Approaches command, which included the Free Polish destroyer ORP Piorun and the corvettes HMS Heather, Orchis, Narcissus, and the Free French FFS Renoncule. See Peter Coy, The Echo of a Fighting Flower: The Story of HMS Narcissus and B3 Ocean Escort Group in World War II (Upton-upon-Severn, 1997).

${ }^{2}$ Captain (D[estroyers]) - traditionally the captain commanding a flotilla of six to eight destroyers, but as used here probably refers to a new form of the appointment that developed because of the unique circumstances of the Battle of the Atlantic. Captain (D) became a shore appointment (with the support of a substantial staff) at major escort bases with responsibility for the readiness of the escort warships operating from that port.
} 
latter quiet, attractive chap, ${ }^{3}$-a very decent lot. Edwards is R.N., a Welchman a specialist in anti-submarine work; an extremely wise \& capable fellow. The Captain arrived later, - Tait, R.N. D.S.O \& twice mentioned in dispatches. ${ }^{4}$ He promised me excitement, at least hoped for it.

Weather was rough windy and rainy: did degauzzing, sailed at 1600 or thereabouts and put in for the night down the Clyde. On the way, I went to the flag deck with the Surg \{eon $\}$. Lt. and watched the 3" \& 4.7 guns blaze away at a target which was supposed to be lighted by our search lights, but the mist was still bad: however star shells were used with good effect $\&$ they hung in the sky by parachute and gave out

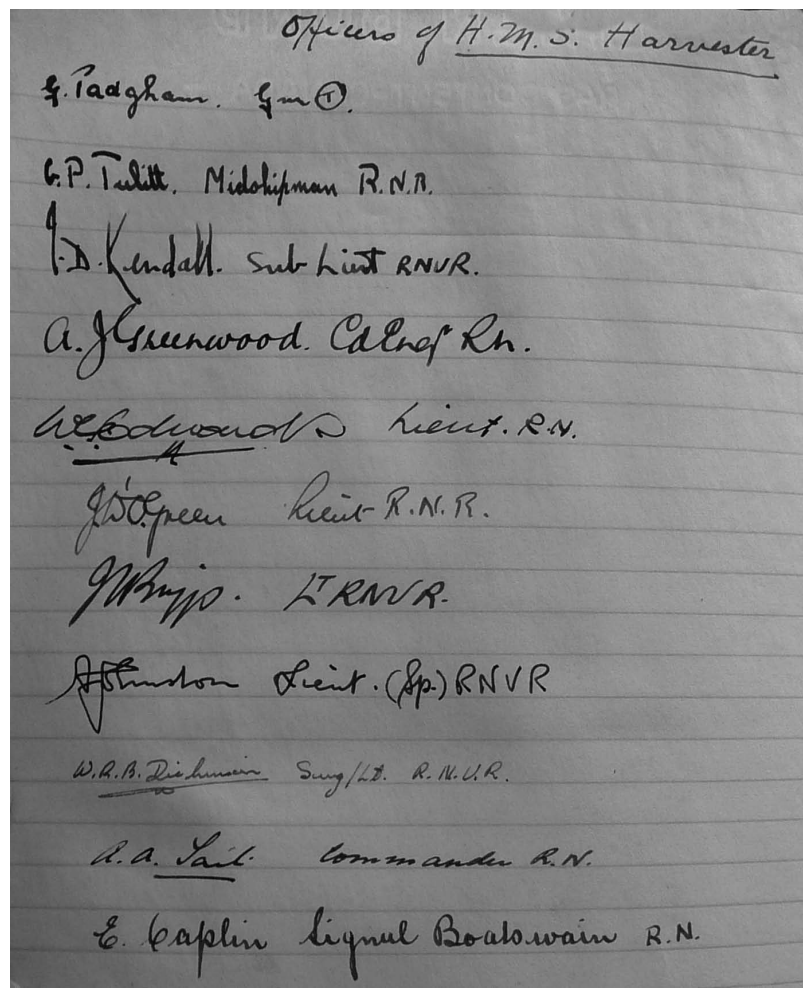

Signatures of the officers of HMS Harvester, September 1942, collected by Graham in his diary notebook. (Queen's University Archives 2151.5, box 7 , file 9 )

\footnotetext{
${ }^{3}$ W.G. Edwards, Lieutenant, RN; J.W. Briggs, Lieutenant RNVR; J. D’O. Green, Lieutenant, RNR; J.D. Kendall, Sub-Lieutenant, RNVR; W.R.B. Dickinson, Surgeon Lieutenant, RNVR; G. Padgham, Gunner (T) [RN]; A. Johnston, Lieutenant (Sp.), RNVR; A.J. Greenwood, Commissioned Engineer, RN; G.P. Tulitt, Midshipman, RNR; E. Caplin, Signal Boatswain, RN [latter for passage only]. Officers' signatures, UK diary notebook.

${ }^{4}$ Arthur André Tait (1904-1943) entered the Royal Navy in 1917, was lent to Royal Australian Navy as an exchange officer 1932-1934, and was commanding officer of four destroyers during the war: HMS Walker January 1940-February 1941, HMS Hesperus February 1941-February 1942, HMS Achates March-July 1942, HMS Harvester August 1942-March 1943. Distinguished Service Order 16 June 1942 (sinking of U-boat [U-93 on 15 January 1942]); Mentioned in Despatches 1 January 1941 (New Year's List), 25 June 1942 (Murmansk Convoys March-May 1942), 1 June 1943 (sinking of U-boat [U-444, with Free French Ship Aconit on 11 March 1943]) (http://www.unithistories.com/officers/RN_officersT.html, accessed 16 March 2016; decorations confirmed in the online edition of the London Gazette https://www.thegazette.co.uk/, accessed 1620 March 2016). Tait was credited in post-war reassessments by the Naval Historical Branch with the destruction of $U-208$ on 17 December 1941, when he was in HMS Hesperus; ironically, HMS Harvester was in company and shared the victory (Axel Niestlé, German U-boat Losses During World War II: Details of Destruction (Annapolis, MD, 1998), 283).
} 
considerable light. The flame of the guns was impressive, $\&$ the concussion forced us to use cotton in the ears.

\section{Aug. 30 Sunday}

Prayers at 10 o'clock, following which the Captain announced that the N. Atlantic "was lousy with submarines" which had come up from the Caribbean and urged the congregation to be on the alert.

11-12. - weather was still foul, but we blazed away at a towed target; I was on the main deck \& even with cotton in my ears I found the blast hard to take, especially in the stomach; 16 inch must be frightening like a 2 ton bomb.

The beer is good, $\&$ the food is too; $\&$ there are a number of good books to read - if I feel like it. The $\underline{1}^{\text {st }} \mathrm{Lt}$ wants me to instruct the snotty in history and give a lecture which I shall do if I am not sea-sick.

4-5 pm. a plane was supposed to tow a sleeve for A.A . practice, but returned due to bad weather, so the 3" shot up smoke shells, and the 4.7 and the Oerlichens \{Oerlikons\} \& pom poms blazed away, latter with tracers. - some of the shooting was very good, although the smoke dissipated quickly \& once was masked by clouds.

Beer \& a good chat with the Captain; dinner, chat with Lt. Edwards, to bed, 12. in Captain's suite, after a very hectic day, during which time I rushed off a few letters to post at Londonderry.

Edwards thinks Germans are more likely to attack U.S. \& Canadian-protected convoys if they know as they are likely to know, abilities of various destroyers as anti-submarine attackers. British seen to have edge in this training so far.

\section{Origin of Asdic}

Allied Submarine Detection Investigating Committee.

Used to detect submarines under water within reasonable distance - say three miles or less by echo. "Dome" enclosed in quartz is lowered below ship's bottom and can be raised when speed is increased, or on entering harbour.

II R.D.F. (a) behind bridge and encased in special glass is aerial for picking up subs. On the surface within greater distances, say 15 miles by echo; used in fog or at night and echoes are read from a screen.

(b)Below (with pronged aerial attached to mast) is R.D.F. for detecting approaching aircraft; works on same principle as R.D.F. (a).

III Aft is the H.F.D.F. - High Frequency Direction Finder for picking up messages from German subs and thereby getting information plus checking on their position. It receives only; does not send out energy and get echoes.

IV Wireless and Radio Telephone - former used for transmission and reception of coded messages or cyphers from Britain, etc; telephone used in convoy on certain, chiefly emergency, occasions.

V. Visual Signalling - almost entirely by light, semaphore is rarely used, except to signal from bridge to stern on occasion, should ship's telephone go off. 


\section{At Sea}

\section{Aug. 31, Monday}

We hauled anchor at approx 3a.m. for Londonderry at daybreak. Off the Irish coast the exercise of Hedgehog was first tried - an entirely disturbing experiment. A submarine towing a red buoy or \{word illegible\} (which acted as an indicator) was traced down by means of the echo device \{words inserted:"Asdic Recorder"' which provides sounds and a written record on a graph; this record tells approx. bearing $\&$ range, \& as the destroyer gradually approaches "hedgehog" is told to stand ready; at approx 50-75 yards fire is given and a series of 12 (or ord. \{ordinarily?\} 24) bombs shoot into the air parabola fashion and dive on the sub. Lt. Edwards scored 2 hits we discovered later, - the bombs being "duds" which however, must have rattled the sub. a bit; in the air they look like the curved back of a prickly hedgehog.

Depth charge attack was also tried but without dropping the charges, merely estimates on position of the buoy; needless to say, the officers in charge did not see the position of the buoys which indicated the position of the sub until immed $\{$ iately $\}$. after the exercise.

Two smoke candles appeared at 1200 indicating that sub. was surfacing which she did; \& signals were interchanged - morse electric light given \& read with amazing speed. Then the sub submerged again, \& exercises were continued with $\underline{\text { Piorun, }}$, our Polish colleague, a newer and heavier armoured destroyer, painted a brilliant blue, the latest experiment of Lord Mountbatten. ${ }^{5}$

By one we had entered Loch Foyle by Londonderry, with the Free state on one side \& northern Ireland on the other; various motor boats from the Free state came alongside, and sold tomatoes, bread, butter, cheese, eggs \& duck eggs at extravagant prices, since even the Navy is rationed.

We had a bit of sun at last; the sea was smooth and as we left the harbour after oiling again (from the President Sergeant ${ }^{6}$ ) the Free State looked lush $\&$ green and so like an impression in a picture book, as we passed it on the port side. - Two Am $\{$ erican $\}$. destroyers passed us coming in. I ate a hefty supper, climbed the bridge and looked to sea. We should pick up the convoy to-morrow; there is evidently no fear of subs. close to the coast $\&$ and our own mine fields.

Nonetheless we don our Mae Wests, looped above the waist, with a long tube dangling around the armpit to be blown if required, \& provided the energy is obtainable. We sleep with clothes on, taking off only coat \& shoes, \& leaving on

\footnotetext{
${ }^{5}$ ORP Piorun was built as the N class HMS Nerissa. She was transferred to the Free Polish forces in 1940 to replace the ORP Grom.

${ }^{6}$ French tanker, seized by Britain in July 1940. Sunk on 18 November 1942 while on passage for North America in convoy ON 144 by U-624 (http://uboat.net/allies/merchants/2443.html, accessed 16 March 2016).
} 


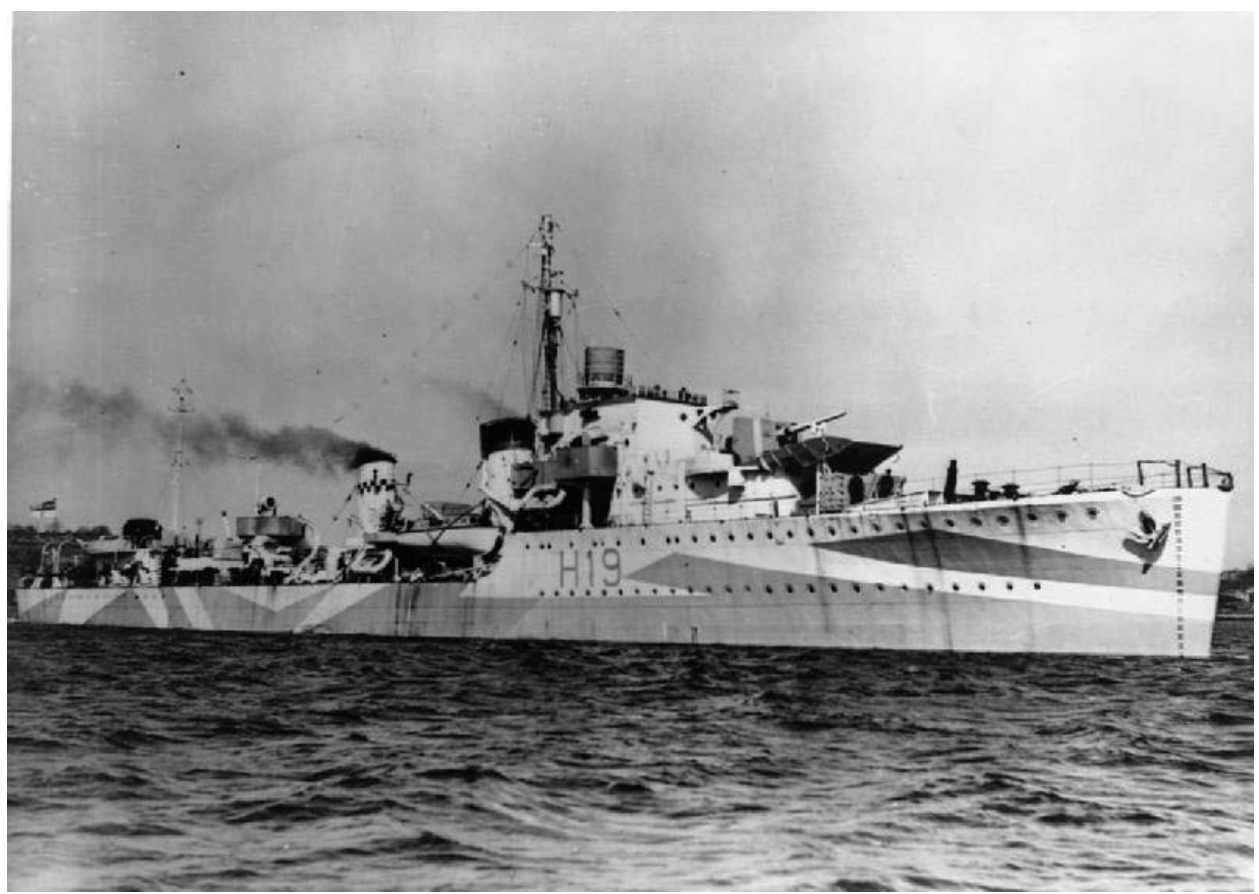

HMS Harvester (Imperial War Museums, coll. No. 8308-29, FL 22661)

Mae West. (My Vitabuoy ${ }^{7}$ turns out to be a very useful watch coat, as well as a good substitute for the Mae West, but in daytime I wear both - not that either would be any good in these heavy seas and present cold.

\section{At Sea}

Sept. 1. Tuesday

Woke up today about 3-4 a.m. to what seemed to be a howling gale which made sleep impossible, and started that queezy feeling in the stomach. Bits of furniture crashed about, and bulkheads groaned and crackled as the fuel oil shifted underneath; I thought at first the reverberations were from the falling weight of water. No breakfast - and feeling miserable; apparently half the company are affected mildly or badly; tried some bovril for lunch plus a biscuit, but no good; only an apple stayed down. However, I finally pulled myself together \& went on deck to find the sun shining which made things seem better; down below I had thought every dive the ship made must be her last.

It was interesting on the bridge altho' hard to stand upright, the ship swaying $45^{\circ}$ list; the convoy came in sight spread out in a wide line - 22 ships (with two

\footnotetext{
A great coat/flotation device from the 1940s.
} 
laggards $)^{8}$ and going about 3 knots - desperately slow. We took position in the van; "Piorun" in rear \& signalling began. It appears that no. $83^{9}$ a Swede on previous night had kept navigation lights on for an hour \& "behaved in a suspicious manner". Corvette Orchis (one of four - Heather, Narcissus \& Free French "Renoncule") asked if might machine gun her if this happened again. O.K.' $\mathrm{d}$ by Captain Tait, who said by any means necessary. Contact made with Commodore Taylor in a large Norwegian three master which is going to Halifax; the remainder go to New York under American escort.

Positions of various U-boats identified by R.D.F., (we had passed by one in the morning) they appear to be scattered in groups of two \& three along the way; according to the Warrant Officer whom we picked up at Londonderry, his outward bound convoy was tackled by three and the "Assiniboine" suffered some casualties in wheel house before ramming her; everyone except coxswain was killed there; Tucker was aboard \& watched the whole show from the Direction turret (from which he was unable to get down in any case but which he apparently did not wish to leave)..$^{10}$

The Convoy is dreadfully slow, and as the Captain said - "no wonder we suffer losses." Merchant ships making three knots; if the weather improves we should add up to 6 or 7 perhaps, but even that is not good for war-time. It is a scandal that better merchant ships were not built. We zig-zag slowly in front at 6-7 knots which increases the violent motion of the boat; there was one U-Boat alarm, but apparently the echo direction finder had located a whale.

Bridge air improved my health, and I ate supper and enjoyed it; the ship is still rolling horribly and groaning in the oil tanks, but I hope to get some sleep. From all appearances we shall be another 12 days to Argentia with this lousy convoy; the Capt. is annoyed too. I could possibly, he suggests, switch to the Commodore's

\footnotetext{
${ }^{8}$ Tait's report of proceedings states there were in fact 23 merchant ships (Report of Proceedings Convoy O.N.S. 126, 14 September 1942, DHH 88/1 pt. 23, courtesy of Robert Fisher).

${ }^{9}$ For ease of navigation and security against flank attack against the exposed broadsides of the merchant ships, they sailed in large number of short columns, each column with only a few merchant ships sailing one after the other. The merchant ships were referred to by their position in the convoy; no. 83 would be the third ship in the eighth column, probably towards the end of the outermost starboard column, and thus in a good position surreptitiously to signal to U-boats that tracked convoys by running fast on the surface but at considerable distance to avoid visual or radar detection.

${ }^{10}$ HMCS Assiniboine rammed and destroyed U-210 on 6 August 1942 while escorting the eastbound convoy SC-94. The official historian of the Royal Canadian Navy, Dr. Gilbert N. Tucker (1896-1955), a combat veteran of the Canadian Corps in the First World War, was in Assiniboine to witness seagoing operations. A fire in fact forced evacuation of Assiniboine's wheel house, except by the coxswain, CPO Max Bernays, who remained at his post to manoeuvre the destroyer; he received the Conspicuous Gallantry Medal. Gunfire from the surfaced $U-210$ killed one Canadian seaman and injured 13 others. W.A.B. Douglas, Roger Sarty, and Michael Whitby with Robert H. Caldwell, William Johnston, and William G.P. Rawling, No Higher Purpose: The Official Operational History of the Royal Canadian Navy in the Second World War, 1939-1943, vol. 1, pt. 1, (St Catharines, ON, 2002), 506-507.
} 
Norwegian ship which goes to Halifax, but that would mean another 2 or 3 days, \& I may be able to fly from St. John's.

\section{$\underline{\text { At Sea }}$}

Wed. Sept. 2.

Sea calmer, although still rough; sun during the morning. I remained on the bridge until action stations exercises at noon. A Flying Fortress circled us several times and exchanged signals. Lt. Edwards told me that during his night watch he sighted a suspicious looking dark object, and began to stalk her, then he noticed another; and another. Looking at his magnetic compass, he discovered his Gyro compass was $180^{\circ}$ out, and that he was stalking his own convoy.

It is a laggard convoy doing little more than 4 knots which will lengthen the trip considerably. At the same time, it is a handsome sight -22 vessels stretched out in a broad horizontal line escorted by 2 destroyers and 4 corvettes. (At night, they close up and escorts guard the flanks, \& not as in daylight, Harvester in van and Piorun in rear.

Captain says the glass is falling like a stone, which indicates more bad weather: it was almost impossible to sleep last night due to the roll, for my bunk has no protective bars or netting, \& one is likely to be bounced out.

Snotty is still ill, not merely sea sickness but stomach pain, which Dr. cannot diagnose; chief engineer is recovering and "Guns" looks less green. They have removed the 'slops' pail from the bridge, altho' it may have to brought back if the wind increases. I must $(2: 30)$ return to the bridge \& look around.

The glass is still dropping and it has become much rougher - rain \& misty; at times the convoy disappears behind us; whereupon we slacken speed \& let them close up. 4 knots is apparently still the rate.

By 6 sea had increased, \& at supper-time 7.30 (clocks back one hour) furniture was moving about perilously. Fortunately, I had recovered from my sea-sickness \& was able to eat well, but things were moving about dangerously - tables, chairs etc. chasing around. I should hate to think of those 30 or so mines \{depth charges?\} running a muck on the rear deck.

It is difficult to walk to the bridge; owing to separate bulkheads there is no interior passage way \& walking has been eased by ropes \& loops on pulleys; an electric alarm bell at the aft ladder may be pressed for "man overboard."

Sleep was difficult enough last night; to-night it will be out of the question; no man could possibly stay in his bunk.

W.T. From England reports no subs. in our immediate vicinity. Apparently they can place most of them by listening in the U-boats calling their own home bases. Similarly they hear all ours, \& probably decode most of them. 


\section{At Sea}

Thursday Sept. 3

A bad night, with gale increasing and no one could sleep; I was not sea sick but it was simply impossible to lie in the bunk without holding on to the bed rail and then were no side lashings; a hammock would have been far more comfortable. In addition, the oil below roared around from side to side as the ship rolled making the sides and bulkheads crackle like a biscuit tin.

Ate a fair breakfast but everyone was a bit depressed; convoy is just about standing still, 11/4 knots, and we are only about 300 miles from Ireland. I have never seen such waves, and the wind unfortunately is against us; even the stern is submerged occasionally as we slip over the crest, balance precariously for a moment high in the air \& then slither down in a mixture of white spume and green lather. For a time the upper deck was closed to pedestrians, and watch keepers or signallers had to telephone so that the ship could be put head-on to the sea to enable them to go forward. I did not go to the bridge all day - but got thoroughly soused once on the stern saving a few dry spots by leaping on a depth charge, but exposing my seat; so I now wear my civilian pants whilst the others dry.

Excellent sausage rolls for lunch which improved disposition, but it is terribly depressing merely holding our own against the waves \& little more. According to $1^{\text {st }} \mathrm{Lt}$., we might have to turn back to Londonderry if weather fails to improve, owing to lack of oil. That would be disastrous.

We had to turn around about 1400 having lost the convoy; decks were cleared $\&$ bulkhead door was closed to prevent stern seas from pouring in; in ten minutes we found them rather badly scattered about, and turned again. In such weather it is almost impossible to keep formation. On the bridge I was told the wind was terrific.

I telephoned the bridge and enquired re. barometer; encouraging reply: "barometer rising, sir." But the swell is still terrific - mountainous, although the sun is shining a bit and the wind may be dying down.

At 1600 or there about this "dot-dash" A-A signal on the electric alarm called Action Stations which meant business; everyone scurried off \& I grabbed my hat \& coat $\&$ tailed along. Ratings removed primers from the depth charges, so that near misses or machine gun bullets would not set them off on deck. In the heavy seas this was a ticklish job.

Turned out to be one of our planes - a silver coloured Liberator, which eventually signalled its identity, circled around \& flew back. Next time - I hope I travel by plane; the curse of this trip is the appallingly bloody weather which holds us down to little over a knot; return to Londonderry would be the last straw. The Capts. cabin is a near-wreck \& sometimes my coat which hangs from the ceiling swings out parallel to the deck (like Charlie Chaplin's watch in the "Dictator"). Looks like another bad night; - Snotty is still seasick; thank God I am spared that. Boredom is bad enough. 
W.T. From England reports we are being shadowed by U-Boats. However, I dried my trousers by the electric heater \& went to bed for the first time sans socks $\&$ pants.

\section{At Sea}

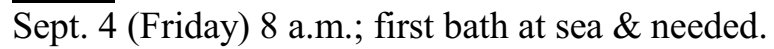

Bumpy night, although got some sleep and should get more to-night since my servant Stanley has put up lashings very neatly \& intricately along the starboard side of the bunk. The mountainous waves (upon which the Captain commented) are away down $\&$ the glass is rising; yesterday were slowed down almost to a standstill, - now we are making about 5 knots. Unhappily during the night, 8 of the convoy fell behind hand and this a.m. the Captain sent 3 corvettes back to watch them; by 3.30 four had rejoined along with escort, two were on the way and two are adrift, which may mean they are lost. [Poor Kendall told me that his father (with the Commodore on board) left his convoy last July, \& was never heard of again.]

Spent good part of morning and afternoon on the bridge; towards 11.00 barometer began to fall again, dark clouds, rising sea and general bad temper: however the Captain thinks it is a secondary depression only $\&$ that things will not reach yesterday's evil extremes. The sun poked out about 3.30 then mist, rain, \& bits of more sun; sea varied, rough but not mountainous. On a dark day, for me it is always menacing and there is of course always the possibility of a U-Boat attack. Apparently the North Atlantic is now thick with them. We are now outside aircraft escort and will not pick it up again until N.A. \{North American?\} planes from Nfld. meet us.

The food continues to be extremely good, only at tea is there any lack of imagination, tho I enjoyed to-day a 4 o'clock egg. In decent weather I might be said to enjoy luxury - sitting room, bath room \& bed room with electric fire; most of the chaps read a good deal and Edwards conducts classes in electrical subjects, or supervises other technical classes after 11 o'clock action stations - seamanship, navigation, etc. for O.S.'s \& A.B.'s. ${ }^{11}$

After action stations today, the small guns, Oerlichens \& pom poms were cleaned of rain by firing a few rounds; the 4.7's \& 3" were wiped at the muzzles to get rid of salt which eats every metal thing \& eventually destroys it if not removed quickly. Curiously enough the armoured glass on the bridge is not affected.

The Captain says he wishes to go to St. John's so we may go along together. He thinks the trip will take 14 days at present rate although we have speeded up a bit. Both Harvester and Piorun thank God still have $75 \%$ of oil left. Yesterday we burned 17 tons.

\footnotetext{
11 Ordinary seamen and able seamen.
} 
The barometer goes up and down and most of us have lost faith in it; the wind is rising, although there is spotty sunshine; the ship continues to roll monstrously and speed remains around 2 knots which depresses everyone.

I suggested to No.1 joining the 2 a.m. watch with Guns, but as things worked out the seas were too heavy to make transit anything but an adventure. According to Edwards they were covering the waist of the ship 3-4 feet deep. Zig-zagging of course increases the roll, as it means repeated movement in the trough; however most of us would not give a damn if the wind were behind us.

Sept. 5. (Saturday)

A bad night despite the lashings on the side; it was too rough to relax, \& I did not get any sleep until about 2 a.m. \& after that fitfully. Glass is rising; but still windy.

Captain said that the laggards had or were gradually catching up, with the exception of one tanker which developed engine trouble during the night and had to put back to U.K. on one engine but with a following wind. [This evening, Captain told me it was still presumed safe, although an easy mark for a submarine.]

Weather seems to be improving Caplin (Warrant Officer, Signals \& also a guest) took some pictures which he promises to send me; it turns out that Green, the Navigating Officer comes from Melton Mowbray and is an old friend of Ken's and $\{$ Gus?\}; indeed an old ship mate of Ken \& knows the family well - again the adage - a small world!

Barometer means little, wind comes and goes and like the rest of the company I curse the sea, and say bugger and bitch more frequently than is my wont. The Captain is fed up both with the elements and the slowness of the convoy, \& the Commodore used strong language re. the weather in his last signal. I understand that Commodores get a month's leave after a to- \& fro trip, which they deserve. (Brockington is keen to give a broadcast on their work.) ${ }^{12}$

Saw the last admiralty signal - 12 subs in our area, although not in immediate vicinity. The Captain has so far in his career "done in" two and lusts for more; he is inclined to think we shall not reach St. John's until Monday, Sept. $14^{\text {th }}$; hardly enough oil to reach Argentia.

At Captain's earnest request - he certainly goes out of his way to look after my needs - "Guns" got me another pillow. Part of one tooth broke away following an Edwards' toffee, but there is fortunately no exposed nerve.

\footnotetext{
${ }^{12}$ Leonard W. Brockington (1888-1966), a British-born Canadian lawyer, civil servant, and broadcaster. Anxious to contribute more directly to the war effort he had gone to London to make broadcasts on the Canadian and Commonwealth contributions for the British Ministry of Information.
} 
Examined the wheel house and R.D.F. chamber, cursed the weather $\&$ the water again, and as in cattle boat day $(1925)^{13}$ longed for the land. [ I only hope to find they will fly me from St John's to Ottawa. ]

1800. getting rougher again damn it; I have promised drinks all around if they get me one decent day.

Weather improves again, little mist; good supper and plenty of talk afterwards. 2 a.m. "Guns" woke me, and I clambered out putting on shoes and coat; we stood on the quarter deck for 5 minutes to get my eyes accustomed to the dark; then walked forward to the ladders and climbed to the bridge, being joined 15 minutes later by No. 1. It was a dark night no moon $\&$ a bit of mist; with difficulty one could make out the leading convoys ships. One has a tendency to go to sleep which must be overcome; it is a peaceful spot in the night with whispered conversation, cocoa later on, and biscuits and cheese.

I visited 172 R.D.F. ${ }^{14}$ and watched the pattern to responses dance in the screen giving bearing $\&$ range of our own ships or any enemy which might appear. Asdic was used only as hydrophone to catch noise, since rest of apparatus might (by sending of energy) give us away to the enemy. 12 subs. acc\{ording\}. to Admty. report are in the area about; but not immediate vicinity. At 4 o'clock watch relieved and I turned in, to sleep until about 9.

Chief says we may hit Argentia on Sunday week, that escort will meet us 400 miles east of Nfld.

Sept 6 (Sunday)

Up late \& had a corned beef sandwich instead of breakfast, plus a lime juice. $\underline{10.00}$ On the bridge - quiet swell, north w. wind, misty and bits of rain. Signal came through - U. boats in vicinity; Piorun's R.D.F. showed one on either bow, and a corvette came rushing through the mist on our port side to signal further information. The Captain was summoned, depth charges were fixed and HE shells placed on trays of the forward 4.7. We all peered over the glass of the bridge, the captain hoisting himself on the edge occasionally to try to penetrate further than 200 yards or so which was all we could glimpse of the sea. Close at hand were 2 U-boats on the surface, and if the mist had suddenly risen we should have seen both of them. Either by good luck or bad (said the Capt.) we had travelled into a nest of them, for he doubted if with poor visibility they could have picked us up. As we came closer, every one 'tensed up', speed was increased, and we waited for the moment when one

\footnotetext{
13 A reference to Graham's first Atlantic crossing, when, as he later recalled he was "entranced" by the British Isles. Paul T. Phillips, Britain's Past in Canada: The Teaching and Writing of British History (Vancouver, 1989), 116-117. We are grateful to Professor Phillips for responding to questions about his path-breaking work on Graham's career, and providing copies of the notes of his interview with Graham.

14 A slight error; in fact it was type 271 microwave radar; Graham describes the unique plexi-glass housing for the antenna earlier in this piece.
} 
or both should appear, at which time the forward gun would let go high explosive, $\&$ if he dived, depth charges to follow. The No.1 was feverish in his desire to get one, tho' completely calm in the arrangements he made. The Capt grinned lustily from time to time, \& peered over the glass. Unhappily, the echoes (had put on the Recorder as we closed up) grew dimmer; \& since we could not leave the convoy to chase him, we lost track. Action had been so close; we were prepared for it, and there was kind of a let-down as reported echoes dying away. ${ }^{15}$ [It is a curious sensation to be so completely dependent on echo and sound for direction; it has revolutionized war at sea by supplying so much more accuracy, e.g. the Hood was sunk by second salvo, R.D.F. range finding. We had ship to land R.D.F. , but not at that time, ship to ship. $]^{16}$

Snoozed a bit in the afternoon; thence to bridge. We were doing 80 to 90 revs. (9-10 knots) in a quiet sea, moving zig-zag ahead of centre of convoy like a ghost ship: visibility limited sometimes to $100-200$ yards. At one time foghorns were sounded on the wings to give positions, there was of course a chance that German earphones would pick up the notes, on the other hand, the danger of a scattered convoy was even greater.

Narcissus reported that No. 43 - a tanker was missing; Commodore was informed [at latest (1900) no news of her; two laggards had caught up. [The Commodore's "three master" looks as if it had seen better days, \& has I believe a bit of boiler trouble]

15 Here is the U-Boat headquarters report on operations against ON 126 on 6 September 1942 (Directorate of History and Heritage, 79/446 pt. 6): "U 608 reported 2 destroyers in AK 9399 at 0959, course 2200. As these may be part of the expected convoy, which according to dead reckoning should be nearby, U 584, 594 and 96 were ordered to act on this report. At 1042 U 594 also sighted a destroyer in AK 9369, which, from its position, could have been part of the starboard outer screen. Operations Control then decided to operate the whole of Group "Vorwärts" and gave orders accordingly. U 594 could not shadow for long in the rain and bad visibility (about 1 mile). The last position of the destroyers reported was at 1550 in AK 9616 according to hydrophone bearing. U 608 also reported rain and fog, visibility 500 meters. At 1035 she was forced to submerge in AK 6675 by destroyers and at 1420 picked up one steamer and 2 destroyers, course 2500 , speed 8 knots, by hydrophone in AK 9625. As visibility deteriorated the boat did not succeed in shadowing. Last hydrophone bearing at 0500 from AK 9468. Group "Vorwärts" has so far continued to operate against the suspected convoy as visibility is expected to improve and there should be a W-bound convoy in this area. It is intended to break off the operation after sunrise if no contact is made by then." Tait was thus correct in his report of proceedings that "thick" weather prevented the U-boats from closing to attack, but not in his conclusion that it was "unlikely that the Convoy was sighted." (Commanding officer, HMS Harvester to commander task unit 24, 14 September 1942, Report of Proceedings Convoy O.N.S. 126, 14 September 1942, DHH 88/1 pt. 23).

${ }^{16}$ In fact both the British and German warships were fitted with fire control as well as search radar, but it was the search radar that made the vital contribution by allowing the ships on each side to locate and track the enemy prior to the engagement. Fire control during the battle appears to have relied on visual instruments. It was Bismarck's fifth salvo that destroyed Hood. Derek Howse, Radar at Sea: The Royal Navy in World War 2 (Houndsmills, UK, 1993), 90-97. 
Admiralty signal that two subs. are shadowing us, so our whereabouts must be known. What they ordinarily do is to summon the rest of the pack, \& with sufficient light attack in their own good time, from the surface usually. They are bound to score some hits, (as in Assiniboine convoy where we lost 12) \& possibly lose one or two submarines.

According to the Captain they lack our R.D.F. (172) $\{271\}$ which cannot be fitted to subs. so far as we know, they depend on hydrophones, but for accurate bearing need to actually sight convoy.

Meanwhile in horizontal line we move through the fog, with the two wolves (or more) on our heels; for a moment at 1800 the sun broke through and shone through the west with an unearthly light - a sort of Heavenly City affect which was exceedingly beautiful. Plenty of fun at supper, and the tension of the morning hours has dissipated itself in Sabath \{sic\} evening ribaldry.

Sept. 7. (Monday)

Night watch again, 2-4, misty colder but fairly smooth. "Guns" brought up biscuits and cheese and the regular cocoa was forthcoming. No alarms although whistling noises led to investigation by the $1^{\text {st }}$ Lt., who bawled out the S.D.O. \{submarine detection officer\} for not giving him notice; after an interval it became clear that the echoes were from porpoises or some such marine animals. Captain appeared about 3.30 and looked things over. To bed following lime juice with Guns in the wardroom.

Bath and breakfast about 9.15; a little more wind but visibility still low. No 82 missing during the night and still not found, no 81 's curious conduct during the night being investigated; she speeded up on our starboard during the night, and Orchis' warning failed to bring her back.

Discussed corvettes with $1^{\text {st }}$ Lt., who claimed earlier ones were a wash-out, lacked speed, armament, in short were not capable either of fighting or finding a submarine. The new corvettes should be more efficient, but in general our vessels of all kinds lacked speed in comparison with German or even Italian \{submarines\}.

He mentioned the tragedy of the Asdic, which fell into the hands of the enemy after the Fall of France; also captured intact from Br. destroyer Seal ${ }^{17}$ but this probably after the fall of France - a terrific loss giving their subs. what we have had, $\&$ they might not have found.

In afternoon mist lifted and convoy burst into view again; wind increasing. "Renoncule" reported submarine in vicinity, prepared to counter-attack but echoes died away and attack failed. Still plenty of subs. around but so far no echoes to Harvester.

\footnotetext{
17 This is an unexplained mistake in the diary - Seal was not a destroyer but in fact a Grampus class minelaying submarine captured in May 1940 by the Germans. She remained the only submarine captured at sea by the Germans during the Second World War.
} 
Captain has asked Piorun to leave direct for St. John's, as soon as U.S.S. Cole arrives. [Owing to critical fuel situation, Admiralty has arranged that the Cole plus a Canadian destroyer and a Corvette should come out to release both Harvester and Piorun] U.S.S. Cole should arrive tonight or to-morrow a.m.; the Canadians should get here by Thursday, at which time we shall probably make for St. John's, get oil, thence rejoin convoy and wind up at Argentia.

Glass is rising, but wind has gone from south to W.S.W., \& rising a bit. The sun has come out at intervals, and our speed is kept up, but we cannot compensate for loss of oil during the storm.

No. 82 is still missing, rest of convoy intact. Good work considering the density of the fog.

1800. clear but wind rising \& heavy swell.

The Captain thinks we came through a nest of subs \& that they did not see us; otherwise they would have attacked at night. On the other hand, Renoncule's signal re. sub. he does take seriously, \& regrets she did not drop depth charges $\&$ "shake him up" if in the neighbourhood.

U.S.S. Cole should be in tonight.

Dinner with considerable hilarity; I smoked a heavy cigar and drank a whiskey liqueur which led to endless stories; in the end, when I went to my cabin to prepare my radio broadcast for the following evening, the effects of cigar and mounting seas were too much \& I had to go up on deck to get air; following which I lay down to sleep, till 10, then worked till 12. Discovered that No. 1 while I was asleep had tied (very elaborately in green ribbon) a baby's nipple to my trousers - a neat bit of work.

Sept 8 (Tuesday)

An uncomfortable night - heavy seas \& few of us slept really well. During the night U.S. signalled that 2 subs. were shadowing us astern and Admiralty ordered a change of course which was admirably accomplished by the Capt. by means of light signals - to Starboard.

No. 83 fallen astern and temporarily lost until U.S.S. Cole picked her up on the way in. 82 is still missing and No. 43. As soon as U.S.S. Cole arrived she took Piorun's place on the port bow, and Piorun showed her heels to us at 20 knots, heading for St. John's to oil; she should rejoin the convoy about Sat.

Sun came out, and although swells were heavy, it was a pretty decent day, with odd rain squalls. I spent the morning working on my radio talk, which was given at 1800 in the office over ship's radio, and seemed to be reasonably well received, altho' the Capt. doubted if I could find the word "illogicality" in the dictionary.

Chief Signalman taught me the differences between International Mercantile \& R.N. code signalling by flags, which (former) the convoy uses almost entirely.

I am gradually learning to walk the deck at any angle, and to avoid over-leaping swells; however one must careful as I have seen two men slip, and others have gone overboard. 
The Capt. tells me that unlike 1914-18 and 1939, no ships try to get ahead of convoy these days; the life of the single ship is too tenuous, and there are no other ships to pick up survivors; the chances of a single boat being found in these waters is not great.

The great change in U.boat tactics is the surface attack by 4, 5 or more, usually at night; one U-boat can accomplish little but a group is almost certain to make a haul.

The Canadian corvettes Chambly and - should reach us, possibly on Thursday; \& Capt. of Chambly will take charge of the convoy, when we "shoot off" I hope, for St John's. The Capt says St John's is probable.

I went on middle watch at 2 , but got sleepier \& sleepier \& finally turned in a little after 3, following cocoa and corned beef sandwiches. Misty cold, fair visibility although we did get off on convoy's beam by mistake.

\section{Sept. 9. (Wed.)}

Fairly heavy seas, then calmer, alternating sunshine and cloud. The Cap. was apparently instructed to oil at sea and arrangements were made despite the groans of the Chief \& myself who prefer to go to St. John's. However, as things look now, we shall go to Argentia in any case, which will be a bit of a nuisance, although I shall look forward to seeing the place. The Commodore is leaving convoy in $\{\text { illegible word }\}^{18}$ ship for Halifax, but I prefer to stick with Harvester \& hope to fly to Ottawa from St John's.

Lunch was a bit grim; everyone slightly fed up with the weather. Afterwards I read bits of Collie Knox Atlantic Battle $\{$,$\} a nauseating book which is unfortunately$ introduced by Admiral Sir Percy Noble. The Wardroom howled in amusement and rage at his worst sentimentalities.

We are now getting plenty of Nfld. \& Louisburg signals as well as U.S. - e.g. Cape Cod. C.C. Nfld. ${ }^{19}$ reports a U-boat near Bell Island (by St John's? ${ }^{20}$ which is being attacked. It rained heavily in afternoon for 2 hours, but it was good to get out of the murky Wardroom with its heavy-eyed pontoon ${ }^{21}$ players, and get freshened up on the bridge; the air was cold.

\footnotetext{
18 The word might possibly at a stretch be "Inger" and the convoy included Ingerfen and Inger Lise, both Norwegian ships bound for Halifax. The convoy commodore, however, was in another Norwegian ship, Rena, also bound for Halifax (NSS 8280- ON 126, reel C-5521, LAC, RG 24).

${ }^{19}$ Presumably "commodore commanding Newfoundland," a title that had in fact changed in December 1941 to "flag officer Newfoundland" when Commodore L.W. Murray, RCN, was promoted rear-admiral.

${ }^{20}$ Graham's guess is correct. Bell Island in Conception Bay was the site of an iron mine and on 5 September $U-513$ had just highlighted the vulnerability of its anchorage by sinking two ore ships in a bold daylight submerged attack (Douglas, et al., No Higher Purpose, 449).

${ }^{21}$ Card game similar to Black Jack.
} 
Supper was a success; \& I provided Dram Buiey's \{Drambuie\} which aided good spirits of Doc, No. 1, and the Chief. Went on bridge at $2200 \&$ stayed until 2300 , following which raided the pantry, got a beef sandwich \& to bed.

On account of heavy seas at noon, oiling was postponed, and since we have enough oil to make the grade $(40 \%)$ even with an attack, it is likely the Capt. will not bother to oil at all.

It was a cold night with light seas, the kind of night which makes one fearful of even a solitary sub. To be torpedoed in still water on a sun shining day would not be too bad; on a dark cold night with swell \& waves, a most forbidding and unsettling thought. It is curious how on one night there is a feeling of complete security - or forgetfulness; \& on another one of tension and concern; it is not the torpedo explosion but the water which would bother me. Gray Owl (as S.O. Johnson is called) spent 5 days in an open boat after being t' $d$ \{torpedoed in a tanker. The snotty spent $1 \frac{1}{2}$ years in tankers, petrol as well as oil \& had good luck; even shot down a plane. He was 16 in 1939, now over 18.

Skipped middle watch.

Sept. 10 (Thursday)

Bright sunshine in the morning raised everyone's spirits, and No. 1 had whole outfit at work scraping paint and cleaning up - our first good day since the voyage began. There was an autumn tingle in the air, and even breakfast became an hilarious occasion - dear old Guns grinning like a kind owl, and the Chief smirking at Green's or Doc's worst jokes. Both No 1, \& Green (Pilot) looked worn after a night of bridge, pontoon and watch-keeping.

I watched Green shoot sun with sextant on flag deck. Thence with No. 1 to Asdic room below where I saw the hidden machinery that works the quartz within the submarine echo detector. Also a thrilling female on a Norfolk, Va. calendar - of all places - displaying her comely charms for the benefit of the R.D.F. rating, thence to stern hatch to watch Guns supervise the rum ration; and I was given a tot -very warming \& best Jamaica. Out of the crew of 180, some 93 take the rum tot, the remainder getting $3 \mathrm{~d}$. \{three pence $\}$ instead.

To bridge - patches of cloud but on the whole a grand day; chatted with the Captain and gazed at the convoy - a pretty sight in clear weather -5 ships out of 23 missing, but the smoke of two stragglers could be seen in the distance - two others are definitely lost and are taking their own course - a perilous one - to U.S. Without R.D.F. a submarine cannot pick you up at any great distance - hydrophones only help within 4-5 miles; visual is their surest guide, \& one sub. summons the pack.

Afternoon - stayed on bridge until tea time; Admiralty code came in - $\{\mathrm{ON}\}$ 127 - convoy immediately behind us - \{HMCS $\}$ Ottawa, Sherbrooke etc. attacked in early afternoon by U-boats and two ships sunk, no news as to whether any subs. were nabbed. This according to the Captain is the nest we managed to navigate through by good fortune or fate - or what you will. They do seem to be picking on the Canadian convoys. 
After tea, long chat with Captain on the bridge re. Cambridge, where he was brought up; his family for generations went to John's where his father or grandfather was a don. ${ }^{22}$ He himself went to Dartmouth, and knew Hughes, Michael Lewis and Callendar.

Back to bridge following another hilarious evening in which No. 1 took a certain amount of chaffing for his new orders, which involve saluting on the quarter deck and more respect to officers. Having been razzed for wearing the old school tie (Henry's) with my coloured shirt \& collar, I changed tie to black again, altho' at sea one seems to be able to wear anything.

To bridge about 2100; U-boats located by H.F.D.F. in neighbourhood signalling "B bar" ${ }^{23}$ to home bases re. fuel, position, weather etc. These signals are rushed to the bridge and transmitted to the Captain, if he is in his sea cabin. Left bridge at 1030 with Kendall\{.\} Sub-Lt. \& Snotty in charge; destroyer \& 180 men in the charge of a youth of $21 \&$ a boy of 18 . Main problem is to zig-zag \& keep ahead of centre of convoy approx. and not more than 4000 yards ahead.

Sept. 11 (Friday)

Mixture of sunshine and cloud, - not as fine a day as yesterday by any means, but no seas. Spent some little time on the bridge - saw the Canadian corvette "Rosthern" join us; she has taken up leading position on Port wing. Had a long chat with Captain who feels deeply about question of Canadian-Br. co-operation. For obvious reasons the Australians have always been more anxious to exchange officers \& men for the sake of experience. At the present time, R.C.N. must be $100 \%$ Canadian in every way, one consequence is lack of training in the sense that the full measure of British experience is not utilized, secondly, our shore establishments are manned by young active personnell $\{$ sic $\}$ who should be (\& from the best of my knowledge want to be) at sea; these could be replaced by "unseaworthy" Englishmen etc. (over-age etc) thus sparing \{active?\} blood for the active service. Narrow nationalism is apt to be the curse of any young nation just burgeoning into nationhood \& I fear it exacts a heavy penalty on our war effort in much the same manner as the Americans suffered in 1914-1918 because for national reasons they would not merge with the British or French \& suffered heavy casualties in consequence. Capt. feels Americans have been much more co-operative, example

\footnotetext{
${ }^{22}$ Reference is to St. John's College at Cambridge. Tait's father took a first in the Theological Tripos at Cambridge, and was later principal of Ridley Hall at the university (1907-1927). "Canon A.J. Tait," The Times (London), 5 April 1944, 7.

${ }^{23}$ The British term for German signals sent in codes that condensed standard information, such as course, position, speed, and sightings of enemy ships, into very short transmissions to give the Allies less chance of intercepting them. They were prefaced in morse code by dash dot dot dot dash: the letter B plus an extra dash; hence the British term "B-bar." Ralph Erskine, "Naval Enigma: The Breaking of Heimisch and Tirton," Intelligence and National Security 3, no. 1 (1988), 171-172.
} 
of Ad. M. ${ }^{24}$ who refused to take cognizance of Can $\{\operatorname{adian}\}$ s. in R.N.V.R. because outside his jurisdiction.

To quarter deck - went below for a rum tot - very warming: talked to the Coxswain.

After lunch, snoozed off until nearly tea; to bridge.

Sky overcast again \& wind rising W. by S.W. We meet escort Sunday A.M. 11.30 Greenwich M.T. \& proceed to Argentia at 13 knots.

Supper - very bad beef washed down with a $1 / 2$ pint followed after supper by two Madeiras - Doc, No. 1, Kendall \& Snotty shared.

Signals indicate that $\{\mathrm{ON}\} 127$ is still being followed \& was again attacked last night; they are now about 300 miles astern. Halifax reports shore watcher as seeing a sub., but Capt. distrusts such reports. H.F.D.R. \{HF/DF?\} picked up transmissions but not strong.

About 10 I left the pontoon players in their smoke filled joss house ${ }^{25}$ (the Wardroom) and climbed on deck; sea smooth; I stopped for three minutes to accustom my eyes to the darkness, and then fumbled \& groped my way forward, keeping a weather eye on the ropes for fear the ship should lurch; past the smoke stack, up the triple ladders, on which I have swayed so often during this trip, to the bridge where the usual ghostly types huddled around the binnacle in the half-dusk of the northern lights; there were no shivering banners or shafts of light, merely a steady glow which partly touched the undulating surface of the sea, but visibility was not great. We have taken up night position - starboard of convoy with Rosthern \& Cole to port, \& Heather and Orchis falling back; at night the convoy has armoured sides.

We are now getting Schenectady \& N.Y. music which brings a touch of home, as well as St. John's broadcasts including police news \& accidents at Harbour Grace, $\&$ report of the Nfld. delegation to the United Church Congress in Canada.

We expect to arrive in Argentia Wednesday morning (4-8) or forenoon (8-12). I hope I can wrangle a plane as time is short. The Captain read bits of Atlantic Battle by Collie Knox \& said he nearly puked.

\section{Sept 12 (Saturday)}

Almost a calm sea, ripples not waves; the convoy showed up clearly from spars to rigging, and as the Capt. remarked, was in column for the first time in ten days. He congratulated the Commodore, who as usual, "concurred."

\footnotetext{
${ }^{24}$ Possibly a reference to Rear-Admiral L.W. Murray, RCN, the Canadian naval commander in Newfoundland.

${ }^{25}$ The Concise Oxford English Dictionary, $6^{\text {th }}$ ed. (Oxford,1976) gives meaning as "Chinese temple," which suggests he is alluding humorously to heavy tobacco smoke in the closed space creating the atmosphere of an opium den.
} 
One could smell the sea, it was so quiet; a Digby ${ }^{26}$ from St John's flew overhead and away looking for subs.

Last night No. 127 lost three more ships without apparently getting a single submarine.

We are comparatively safe today; even the wake from a periscope would show up a long way. According to present plans, we meet escort to-morrow morning, thence drive to Argentia at 20 knots \& may get in there by Sunday evening. - U.S.S. Cole left us this a.m. \& Rosthern signalled - "Cole leaving us - what about it?" or something of that foolish order. Capt. who after all is S.O.E. replied "I sent her off with best wishes".

Guns showed me the gyro compass forward which controls the gyro on the bridge; the mess decks are scrupulously clean, \& hammocks are lashed with precision and grace, not just rolled up.

Kendall suggested a 3" shell case as a souvenir \& very kindly arranged to have it buffed and labelled H.M.S. Harvest $\{$ er $\}$. Sept. 1942. Unfortunately there are no P. Stamps so August was substituted.

Lounged on bridge, shell case finished, \& very nicely too, after supper I had the O.S. [Ordinary Seaman] Price who buffed it and ordnance artificer who put on the name in for beer, along with Guns. One bottle exploded and $70 \%$ of the beer went on the Captain's desk.

The O.A. was an especially decent outstanding chap who has signed on for 12 years; he made himself a \{illegible word \} handled knife with a blade made out of a file - a most ingenious affair. Sailors can do anything - cook, embroider, carve, wash, paint, absolutely anything.

After tea, Capt. called me to the bridge, and asked me if I felt like going on a merchant ship to St. John's along with Pieran \{Piorun\}- 2 merchant ships in all. Finally decided to stick with Harvester, as in point of time it would make little difference and I shall see Argentia.

We learn that $\{\mathrm{ON}\} 127$ has lost 7 ships out of the convoy - five subs. are following, and two more are expected to join. One sub. has been reported near us, but transmissions are faint. They have probably forsaken the Banks area in numbers for the middle ocean now that the Yanks are escorting their ships, - plus the extra plane patrols. We should be in tomorrow night if the good weather continues, \& new escort meets us early enough - thence 25 knots to Argentia.

After Pieran \{Piorun\} left, we changed course to new rendezvous, the Commodore blowing horn to initiate the movement, followed by starboard ship a pretty sight to see them turn in line.

About 8.30 we heard depth charges go off - probably Pieran $\{$ Piorun $\}-$ no reports.

\footnotetext{
${ }^{26}$ Douglas B-18 "Digby," an American built twin-engine bomber. At this time the Royal Canadian Air Force's No. 10 (Bomber Reconnaissance) Squadron, based at Gander, Newfoundland flew Digbys.
} 
Went to forward mess deck to play Tambole - the Navy's Housie Lousie ${ }^{27}-$ played one hand, $\&$ then invested a half Crown in the Midshipman who lost. Nabbed a corned beef sandwich in the pantry, - \{wrote $\}$ the odd letter \& turned in.

Sept. 13 (Sunday) At Sea

Stanley brought tea, as per usual at 8 , but I dozed off again to be awakened about 08.30 by alarm bell, ringing Actions Stations - subs - - - - - \{dashes as in original $\}$. Hurried into my clothes and dashed up to the bridge only to find we had run down a corvette. Not on its course - Rosthern. "Not one of us" said Yeoman petulantly down the speaking tube to B gun crew,- "one of them Kinidian corvettes." The Capt. apologized for awakening me - with an eye no doubt to my sleep-laden eyelids.

After breakfast - at which every one except the Dr. looked fed-up and tired as a result of night watches $\&$ the false alarm, repaired to bridge at 10.15 . Fog was thick, \& occasional foghorns squeaked or groaned out whereabouts of Commodore and his wings. \{HMS $\}$ Caldwell, leading new escort had arrived, and foolishly signalled that R.D.F. showed us - bearing, 1 mile range: by the time this was decoded, we had separated; foolish to code messages under such circumstances in view of our proximity. The scene on the bridge was a fascinating study in modern scientific control $-\mathrm{R} / \mathrm{T}$. failed to get Caldwell, and doubtful if $\mathrm{W} / \mathrm{T}$ got through in plain language; but eventually Renoncule got in $\mathrm{V} / \mathrm{T}$ touch with Caldwell \& forwarded our W/T messages.

Meanwhile, we said good-bye to the Commodore, who had the most exacting job of the lot - handling a convoy from a three-masted \& rather seedy looking tanker. He went off to Halifax alone. Meanwhile, through Renoncule we found that Caldwell had the route, so Capt signalled to break off, \& having first sent on our corvettes on the way to Argentia, we followed at 13 knots.

Under ordinary circ \{umstance $\} \mathrm{s}$. we should have used the Costen gun to fire over Convoy papers; this on account of fog, had to be foregone.

More \& more, one is impressed by the value of R.D.F.; in darkness or fog, the dancing green little flames on the screen indicate the presence, bearing $\&$ range of ships, subs. or whales, and a good man can distinguish, although between a sub. and a corvette there is little difference in the size of the echo. Even an O.S. today must be a scientist, and the man of arts must or should be humbled by the complicated machinery by which even a destroyer or Corvette performs its tasks.

P.M. Fog hangs around and keeps us at 12 knots; we caught up with Narcissus, on port bow, Heather is to starboard 5 miles (1500). For a time, the mist cleared \& we had a good view of Narcissus. $\{S\}$ un came out, \& Pilot was able to sight the sun $\&$ take our position. We should be near Cape Race shortly but cannot get in to Argentia until tomorrow morning, so there is no need of hurrying. Capt. sent a signal

\footnotetext{
${ }^{27}$ Both are games similar to North American Bingo.
} 
to Argentia, and to C.C.N.F. ${ }^{28}$ requesting air passage to Ottawa, which I hope may accomplish something, at least make them consider the problem of my journey.

At 1800, clocks went back a half hour; we are due to arrive at 0930 a.m. tomorrow. The mist has lifted and we are bowling along now, I should judge at 15 knots or more. Dinner - my last, I am sorry to say, for I had become very attached to the wardroom (or brothel as I called it to the card sharks). I am afraid I mixed my drinks with some abandon, but it was worth the risk.

Pilot brought in the sad news that the Halifax convoy left this evening, which means Harvester must leave Tuesday night, giving the chaps just one night ashore, which is tough luck. It will be a fast convoy, cf. \{compared $\}$ to this one.

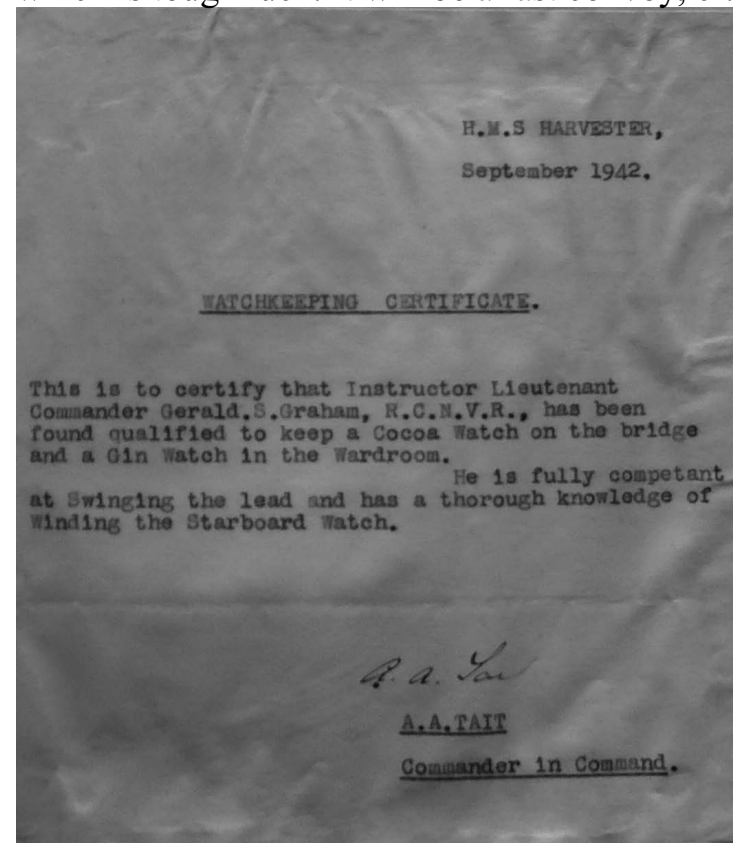

After dinner I was presented with my Hon. Watch Keeping Certificate, a neat bit of writing by No. 1. which I shall preserve as a momento of many nights on the bridge and in the Ward room. ${ }^{29}$

I gave the captain a copy of Br. Policy in Canada 1774-91 ${ }^{30}$ (not for internal consumption) and he very kindly give me the brief history of the Arch Royal. - (30 shillings to messroom staff).

Returned to the bridge about 2200, and chatted with Kendall until 23.20. The mist had lifted, and visibility was fair. To bed around 23.30 and put on my Mae West for the last time, this year at least.

(Monday) Sept 14 - Argentia - Sydney

Stanley wakened me at 7; a cold bath at 7.30 since cook had just started the galley fire. On deck a grand view of Placentia Bay, as we entered little Placentia harbour; rough bold hills, steep cliffs, round, knoll-like islands. We went through

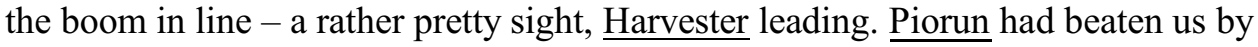

\footnotetext{
28 Presumably commodore commanding Newfoundland.

${ }^{29}$ HMS Harvester, September 1942. Watchkeeping Certificate. This is to certify that instructor Lieutenant Commander Gerald S. Graham, RCNVR has been found qualified to keep a Cocoa Watch on the bridge, and a Gin watch in the Wardroom. He is fully competent at Swinging the lead, and has a thorough knowledge of winding the Starboard watch.

${ }^{30}$ Graham's first book British Policy and Canada, 1774-1791: A Study in 18 ${ }^{\text {th }}$ Century Trade Policy (London, 1930).
} 
a few minutes, having had 24 hours in St. John's, and then rejoined us at Argentia. (The $1^{\text {st }}$ Lieut. tossed two grapefruit on board for Edwards and Capt's breakfast) To the anger of everyone on board especially the Chief (who wanted us to go to St. John's anyway to buy a thermos bottle for his wife) we were ordered by the C.inC. (Argentia) to tie up by the oiler just past the boom rather than go into the harbour and tie with the depot ship which meant land connection, and immediate shore leave for several. To add to the discomfort, the motor boat steering went wrong, and the whale boat had to tow her in, with Snotty looking very disconsolate. (It was his first time in charge of the motor boat.) Meanwhile, since last night's signal had provoked no answer from C.C.N.F. or Lt. Pope (Liaison man with U.S. in Argentia) Capt. Tait signalled v/s \{visual signalling $\}$ asking C.C. Arg $\{$ entia $\}$. if there was a chance of plane travel out of Nfld. Meanwhile, I paced the deck impatiently, watched them tie up to the oiler, very neatly indeed, had breakfast, and worried No. 1, who finally lost patience and said he could keep one thing on his mind at a time - this time, painting the ship, and referred me to the Officer of the Watch, - Guns. To expedite his painting he had a radio rigged aft which played raucously in march time, and "pepped" every one up - or was supposed to.

Meanwhile, the escorts gathered around the oiler like chicks around a hen. On our port Piorun, on the starboard, Renoncule corvette, on the \{ir?\} starboard, Heather and Narcissus. Here were Fighting French with red top-notches on their blue tams, jabbering away in truly Breton style, Poles sturdy and energetic, most of them originally soldiers turned sailor - Americans - on the oiler officers in Kakhi summer uniform, with the ratings the usual melting pot a football team variety, sprinkled with a few negro cooks.

At 9:20 yeoman brought the Capt. a signal-Admiral's plane leaving for Sydney at 9.30 be at the field by 9.15 . What wisdom! However, the Capt. thought it was worth a try - especially since Ry. \{Railway?\} traffic in Nfld. had been abandoned for persons not freight (in my case it was approx. 2 days from St. John's to Port Aux Basques). I did not think there was much hope espec. as a Catalina was seen to take off at 9.30. However, our motor boat was fixed, the baggage tossed in, I clambered over the side, telling Cap. \& Edwards I would see them later. Snotty at the wheel, off we went with a fine bow foam \& plenty of spray. I saw Doc on the quarter deck as we leaped away but he did not see me wave. The jetty was a perilous sort of gallery tacked to the side of a roofed depot; with care I scrambled around \& out leaving baggage behind until I learned the worst. Stopped a motor truck and got a ride to the aerodrome while truck raced across a ploughed field. Discovered that the Admiral's plane - a Blue Goose ${ }^{31}$ - was delayed waiting for Cmdr. McNeill (U.S. Coast Guard). I sent snotty $\&$ his three ratings, who had lugged the baggage over the

\footnotetext{
${ }^{31}$ The Grumman Goose was a small amphibian passenger aircraft widely used in the U.S. (and Canadian) forces. Graham always refers to the "Blue Goose," a designation likely arising from the fact that this particular machine was specifically assigned to the commanding admiral.
} 
ploughed field (a future addition to the landing field) back to the ship after warm farewells.

Waited \& waited. Needham the pilot cursing the delay; went up in a truck to Canteen \& bought some cigs. \& choc. bars. In less than a year Argentia has become a small town of barn-like barracks and offices, growing mushroom like à l'Americaine - By 11 the mist had come over, \& when the Cmdr. arrived having misread the time "Z" (G.M.T.) a couple of hours later than Nfld time (a damn fool way to send a message anyway) decided to go back for lunch to the Mess. Met the C. in C. Admiral Brainard, ${ }^{32}$ a grand chap, LtCmdr Ashton Williams, etc. - a fine and cheery, hospitable group. I like the American good-cheer manners and their warmth to strangers. Had a tremendous lunch, real salad (lettuce) lots of coffee and fried chicken. Signalled Goodbye to Harvester

By 12.30 mist had gone, and after telling Page to signal Sydney N.O.I.C. asking for air passage further, - off in the Blue Goose - (a last glimpse of Harvester on the way - now going up to the Depot ship.) Sat by radio operator while McNeill sat in front with the pilot; flew at about $800 \mathrm{ft}$. in grand sunshine with beautiful view of the Nfld. coast - hard, iron-like cold, steep cliffs dropping straight to the sea; occas $\{$ ional\}. gannetts about, no human beings until we saw St. Lawrence and near it the wreck of a destroyer (U.S.) Truxton \{Truxtun\} driven ashore with a mate in a storm - (about 150 saved, I believe). ${ }^{33}$

Over St. Pierre \& Miquelon - former a good sized town with artificially protected harbour; brown sails of fishing boats gave a pleasant old world touch, we passed over many of them large \& small. Pilot dropped a smoke bomb \& as it burned, he swooped down on it releasing two bombs in simulated sub. attack, - near misses.

After approx. $2^{1 / 2}$ hours we landed in Sydney - not a bump - enquired at R.C.A.F. - Mike McCoskey, who telephoned N.O.I.C. who passed the buck to Mike in the end. I got a seat in the T.C.A. to Moncton leaving in 10 minutes. Unpacked baggage from Blue Goose, paid \$20.20 for fare \& excess baggage, - off again with curtains drawn until we passed Sydney Harbour. ${ }^{34}$ Hostess (petite like Patty Kraft) said might get on to Montreal if vacancy; \& I found I had just enough money.

\footnotetext{
32 Rear Admiral R.M. Brainard,USN, commander Task Force 24, that is the USN bases in Newfoundland and the naval forces operating in the north-west Atlantic. At the time he was the senior Allied naval commander for convoy operations in the north western Atlantic, the counterpart of Admiral Sir Percy Noble, who, as British commander-in-chief Western Approaches, controlled convoy operations in the eastern part of the Atlantic. Brainard had operational authority over the senior Canadian officer in Newfoundland, Rear-Admiral L.W. Murray, RCN.

${ }^{33}$ The destroyer USS Truxtun and navy supply ship USS Pollux ran aground in a heavy storm near Saint Lawrence on 18 February 1942; of the 389 officers and ratings on the two ships 186 survived, in part because of the heroic efforts of the local population.

(https://www.mun.ca/mha/polluxtruxtun/gallery/image-viewer.php? image=pollux_1\&category= ships\&chapter $=1$, accessed 18 March 2016).

${ }^{34}$ A security measure, as Sydney was a major convoy port.
} 
We had perfect view of P.E.I. stretched out before us - the whole island at once, $\&$ how small it is, \& how clearly etched the farms $\&$ roads and the brown beaches; the sun shone brightly as we swept over N.B. woods \& finally landed in Moncton. Here my luck deserted me, for the plane to Montreal had to fill up with mail \& 6 passengers were kicked out; -

No wire or warrant from N.O.I.C. so I bought my ticket \& sleeper, - had a good meal at Windsor Restaurant, walked to Bore Park to see the tide trickle in. Streets filled with R.C.A.F. \& spotted with whores. - strolled about station listening to the engine bells again and the bright lights on the rails and the mournful blare of the Can. whistles. ${ }^{35}$ Caught train at 10.00 \{ "22.00" inserted immediately above " $\left.10.00 "\right\}$ $\operatorname{dep}\{\operatorname{art}\} 10.20$ after wiring Emily ${ }^{36} \&$ mother. [Had previously sent cable to Pamela $^{37}$ from Nfld. \& later to Emily].

Sept. 15 (Thursday) Moncton-Montreal

A fairly comfortable night - altho' the train stopped every 10 minutes; woke at 7 and looked at a perfect day - sun rising over brown fields, cut in Fr. Can. style with narrow strips - fence after fence, stacked wheat sometimes - little villages with church towers, \& now \& then vistas of the St. Lawrence or of grey rocky hills covered with firs and hardwood changing colour. - On the way to breakfast I leaned out and sniffed the glorious dusky autumn air, \& again when we stopped at Riviere du Loup, walked the platform; I had forgotten how beautiful was Canada - autumn is its best season - we shd. arrive Montreal at 7.30, \& Emily may meet me.

\footnotetext{
${ }^{35}$ Canadian? Possibly a comparison of Canadian train whistles with those in the UK.

${ }^{36}$ Winifred Emily Ware, Graham's wife.

37 Pamela Ware, Emily's elder sister, who appears to have lived in London at this time; Graham visited the Wares during his stay in the UK (information kindly provided by John Graham; see also UK diary notebook, entries for 23, 26 and 27 June 1942).
} 